\title{
British Working-Class Writing: Paradox and Tension as Genre Motif
}

Simon Lee

It goes without saying that the literary arts' capacity to analyze and critique contemporary cultural shifts is unparalleled, and British working-class literature grants social historians unique insight into the way class assignations are negotiated and managed. By presenting a mosaic of experience, as well as conceptualizations of class consciousness, British working-class literature mines the aspects of working-class life often overlooked in day-to-day reality. However, inherent within this literature is a paradox: competing aesthetic and political objectives that are periodically at odds. I want to suggest that this paradox echoes the persistence of class struggle, yielding an aesthetic tension that shields British workingclass literature from both complacency and schematization. As other writers in this volume discuss, working-class literature is often indeterminate and contingent, and situating it within genre confines requires critical dexterity. For example, discussing Georg Lukács in his contribution to this collection, Benjamin Balthaser writes that working-class literature is "in tension with the reality it seeks to document" in a manner that produces "a dialectical vision"- a gesture that echoes Eugenio Di Stefano's recommendation to approach such literature as "an evolving genre in relation to different modernization projects" (see Di Stefano in this collection). This dialectical affiliation has been well documented by critics like Ian Haywood, who notes how the emergence of the novel as a bourgeois enterprise reflects a class bias within cultural production-one that tends to exclude working-class perspectives and authenticity in lieu of high-brow modernization and literary

How to cite this book chapter:

Lee, S. 20I7. British Working-Class Writing: Paradox and Tension as Genre Motif. In: Lennon, J. and Nilsson, M. (eds.) Working-Class Literature(s): Historical and International Perspectives. Pp. I 59-195. Stockholm: Stockholm University Press. DOI: https://doi.org/IO.I6993/bam.g. License: CC-BY 
trends $(\mathrm{r} 997, \mathrm{p} .3)$. These exclusions are generally offset by representational modes, such as realism, that simulate authenticityeven in the presence of authentic authorial experience-to such a degree that working-class writing that fails to foreground the jagged surface of reality often feels incomplete. Nonetheless, as Peter Hitchcock has suggested, working-class representation cannot be reduced to a set of material signifiers because class exists as a series of social relations rather than fixed traits or characteristics (2000, p. 23). Consequently, this chapter traces the emergence of British working-class literature, specifically emphasizing the way the genre sustains tension between aesthetic and political aspirations. It concludes that the very notion of an authoritative working-class literature resists formal consummation and is therefore subject to continual renovation contingent upon cultural need.

Numerous scholars have charted the general terrain of British working-class literature, pinpointing key moments and locating cultural production within the dynamics of culture itself. However, given that canonical bias has marginalized working-class voices, academic texts have sought to recover the genre through panoramic coverage rather than discrete angles or nuanced positions. For example, H. Gustav Klaus' The Literature of Labor: Two Hundred Years of Working-Class Writing (I985) argues for a general "literature of labor" with a particular focus on Chartist fiction while maintaining a broad perspective throughout. Similarly, Jeremy Hawthorne's edited collection The British Working-Class Novel in the Twentieth-Century (I984) offers a range of essays that provide a robust overview of working-class writing, leaning more toward intersectional concerns of gender and race. Ian Haywood's rich Working-Class Fiction: From Chartism to "Trainspotting" (I998) is as comprehensive a survey as it is a compelling entreaty for the academic legitimization of working-class writing. Texts like Martha Vicinus' The Industrial Muse: A Study of Nineteenth Century British-Working Class Literature (1974) and Paul Thomas Murphy's Toward a Working-Class Canon: Literary Criticism in British Working-Class Periodicals, I 8I 6-I 858 (I994) present more period-specific synopses, focusing respectively on the impact of economic shifts on literary production while gesturing toward the formation of a burgeoning working-class literary 
aesthetic. Peter Hitchcock's Working-Class Fiction in Theory and Practice: A Reading of Alan Sillitoe (1989) historicizes the cultural dynamics that paved the way for twentieth-century working-class writing, but Hitchcock's primary concern is Sillitoe's contribution to the kitchen sink realism movement of the I950s and I960s. Such overviews are well supported by supplementary accounts like Jonathan Rose's The Intellectual Life of the British Working Classes (200I) in which patterns of literary consumption through memoirs and autobiographical writing are established. Rose emphasizes the autodidactic nature of the British working classes along the way. These approaches build on foundational work by writers like Richard Hoggart, whose acclaimed The Uses of Literacy (I957) not only surveyed reading habits but also argued that reading habits were responsible for shifts in the way class was experienced.

Contemporary scholarship has sharpened the focus by reevaluating overlooked works to elevate their social significance with journals such as Women's Studies Quarterly (I995), Victorian Poetry (200I), PMLA (2000), and Philological Quarterly (2013) dedicating issues to working-class writing. In addition, recent monographs have offered more nuanced analyses of working-class writing, such as John Kirk's Twentieth Century Writing and the British Working Class (2003) which accelerates to the I980s and I990s clarifying how contemporary texts respond to prior moments in the formation of working-class writing. Pamela Fox's Class Fictions: Shame and Resistance in the British Working-Class Novel, I890-I945 (I994) builds on Hawthorn's collection by unpacking gender relations in working-class writing and underscoring developments in the workplace throughout both wars. Nicola Wilson's recent Home in British Working-Class Fiction (2015) develops Fox's work on gender representation-as well as the work of sociologists, such as Joanna Bourke-by investigating the role of domestic space across a range of working-class texts. Wilson emphasizes the home's impact on the formation of class consciousness, showing how working-class fiction's tendency to privilege representations of the workplace only sheds partial light onto working-class culture as a whole. Robert del Valle Alcalá's British Working-Class Fiction: Narratives of Refusal and the Struggle 
Against Work (2016) argues that mid-century working-class fiction can be read as a response to a history of economic and social oppression, insisting that working-class fiction offers correctives to the imposed limits of social stratification. My own research considers the way working-class writing responds to shifts in the built environment. I focus specifically on the way that working-class environs maintained social divisions and how fictional representations imagined alternative ways of negotiating the confines of classed spaces. The goal of this particular chapter, though, is to trace a thread running through the genealogy of British workingclass texts-one whose inherent tension functions to keep the genre of working-class writing dynamic and homeostatic.

\section{Nineteenth-Century Literature: Formation and Development}

While literary references to labor and working people certainly precede industrialization, the standard point of departure for working-class writing in Britain is the nineteenth century-a time that saw significant social and cultural shifts, the cementing of tripartite class categorization, the emergence of the novel within the arts, and the development of realism as a dominant mode of literary representation. Whereas representations of class in twentiethcentury literature are relatively established, the nineteenth century reads more as a crucible, in which aesthetics and political imperatives intertwine in relation to social class. As Carmen Casaliggi and Porscha Fermanis have suggested, the challenge of comprehending the topic of class in the literature of the early nineteenth century can be attributed to disputes in the way that class itself was envisioned following the transition from feudalism to early industrial capitalism, in which economic and political dynamics were destabilized (2016, p. 40). Furthermore, professional writers in the public eye risked alignment to radicals and agitators when publishing work deemed insurrectionist or challenging to the status quo. Poet Laureate Robert Southey, for example, distanced himself from his anonymously-penned dramatic poem "Wat Tyler" when his political enemies discovered and published it under his name in I 8I 7 . This discovery prompted him to dismiss 
the work as the naive scribblings of an excitable schoolboy. Yet, it was Southey who, in I83 I, composed a performative apologia for working-class writing, in which he simultaneously patronizes and praises the quaint vulgarity of lesser citizens (I836, p. I3). Southey's hesitancy to fully embrace working-class writers as legitimate cultural voices mirrors his own anxiety over social positioning but also reflects the new challenge of developing literary art in tandem with ideology.

As Ian Watt outlined, the eighteenth century marked the emergence and rise of the modern novel with the nineteenth century cementing its form through the birth of realism. Nineteenthcentury realist texts represented working-class lives at their most organic and mercurial during this time. For Watt, the development of the novel reflects not just a trajectory within the literary arts, but an opportunity to portray diverse perspectives through verisimilitude:

If the novel were realistic merely because it saw life from the seamy side, it would only be an inverted romance; but in fact it surely attempts to portray all the varieties of human experience, and not merely those suited to one particular literary perspective: the novel's realism does not reside in the kind of life it presents but in the way it presents it. (I957, p. II)

In other words, style and technique are critical components of narrative mimesis, and the social value of the novel is weighed by its fidelity to the world it depicts. Despite Watt's emphasis on Daniel Defoe, Samuel Richardson, and Henry Fielding, perhaps the novel that best defines this degree of verisimilitude in terms of class demarcation is George Eliot's Middlemarch (I87I). Eliot's text serves as a pointed rejection of early ninteenth-century Romanticism, but a fixation on interiority is what distinguishes her working-class characters from the working-class characters of many of her contemporaries whose sentimental representations sometimes bordered on caricature.

By focusing on the provincial exchanges of a tripartite class system, Eliot's novel responded to class schematics established at the time as outlined in Matthew Arnold's Culture and Anarchy (1869)-specifically what Arnold refers to as Barbarians (the 
aristocracy), Philistines (the urban middle class), and the Populace (the working class). While critics have argued that Eliot is as guilty of reproducing working-class stereotypes as her contemporaries, K.M. Newton has emphasized how Eliot's characters reflect unified outlooks and shared interests aligned to new systems of class designation (20II, p. I 53). This distinction, although subtle, is reflected in the fact that Eliot's representation relies less on pathos and more on unmasking social relations that produce systems of oppression. Although Jonathan Rose has claimed that Charles Dickens's support for working-class people is understood through "the role he played in making them articulate" (2002, p. I I4), Eliot moved depictions closer to reality by situating her characters in their native milieu and commenting on the social exchanges that result from their interactions. Yet, Eliot's authenticity-like that of Dickens and other professional writers from the period-was somewhat hamstrung by the author's own elevated social class, outlining a perennial concern of literary representation in general: one of credibility and rhetorical ethos. While such a concern has received significant critical scrutiny (largely resulting in its dismissal as a necessary criterion for working-class writing), the persistence of such concerns cannot be so readily abandoned. Instead, I would argue that such persistent concerns over authentic depiction contributes to the kind of productive tension at the heart of working-class writing itself.

While the rise of the novel and the alignment of realism to depictions of social class tends to reflect more canonical and established forms of nineteenth-century literary production, working-class writing can also be seen to emerge from movements where social and political objectives were prioritized over representational aesthetics. For instance, whereas Benjamin Balthaser, in his essay in this collection, notes that working-class writing in nineteenth-century America was "seldom by them and even more rarely, from their perspective", nineteenth-century British literature saw substantial contributions from legitimately working-class people in both the first and second halves of the century. One of the earliest social reform movements to form bonds with British literary production was that of the Chartists, a radical 
working-class movement with parliamentary reform in mind. The failure of the 1832 Reform Act to produce substantial changes to the electoral system left many working-class people disenfranchised and unable to participate in the political process. In 1838 , the People's Charter was drawn by William Lovett and Francis Place, alongside members of the London Working Men's Association, with the document calling for universal suffrage and the cessation of technicalities that restricted working-class participation based on social position. After the 1839 rejection of the document by parliament, social unrest followed with subsequent petitions presented and summarily rejected. The movement dissolved in 1848 following the rejection of a final petition but with no accompanying insurrection. Despite this, a revolutionary spirit persevered with reformers continuing to advocate for and implement changes over time. Today, Chartism is seen as a catalyst of the democratic process itself, underscoring the necessity of monitoring social power dynamics and making their effects known within culture.

Texts by Yuri Kovalev, Peter Scheckner, Gustav Klaus, and Anne Janowitz, as well as the aforementioned Ian Haywood and Martha Vicinus, have explored the connections between literary production and Chartism in depth. ${ }^{\mathrm{I}}$ Germane to this discussion is the way that the movement viewed basic literacy as indispensable to its social objectives, reflecting not only the rise of a self-educated, articulate working-class people to counter the educated and "legitimate" output of professional writers (such as Dickens and Eliot), but also reflecting attempts at self-emancipation from imposed class confines. The Chartist movement's efficacy can be traced to its use of print media with a series of working-class newspapers like The Poor Man's Guardian, The Twopenny Dispatch, and The Northern Star disseminating speeches and essays as well as didactic poetry. By the time of the movement's dissolution and diffusion into other causes, the genre of Chartist fiction was established, largely penned by movement leaders as opposed to novelists and writers. Thomas Martin Wheeler's Sunshine and Shadow: A Tale of the Nineteenth Century is widely looked upon as one of the more successful extended works of the time. Released in serialized form in 1849 , the novel outlines the decline of the movement 
while forcefully restating the movement's central objectives. However, it is framed in a manner that Rob Breton has described as romantic: "a political melodrama that infuses intellectualizing genres into a sensational form, telling the story of working-class autodidactism while describing shipwrecks and relying on miraculous coincidences" (2009, p. I2I). While the use of sensationalist plot devices blunted the text's didactic goals, Wheeler's approach stood in contrast to representations of working-class people as sentimentalized martyrs primed for religious salvation or caricatures of class distanced from the experiences of British workingclass people. Despite its narrative flights of fancy, Wheeler's text-and Chartist fiction in general-addressed contemporary concerns specific to the characters within the text, as well as the target audience that the text was aimed at. The inclusion of social issues specific to the working-class can be identified as a trope that echoes through much of the twentieth-century's working-class fiction. While the seeds of realism had yet to be fully planted within working-class literature, what emerges in Chartist fiction is an elevation of pertinent topics and concerns associated with a segment of the populace ordinarily marginalized within the arts. However, the movement also reveals the seeds of an aesthetic paradox: the challenge of bridging literary objectives of storytelling with ideological goals.

Such aesthetic challenges continued throughout the remainder of the nineteenth century-a period in which representational tropes like the use of regionalism and local dialect developed in tandem with ideological positioning and social purpose. Still, during the second half of the I9th century, literary consumption reflected an ironic divide: a preference for sensationalist, trashy novels aimed at mass-readership while literature that sought to push the envelope of verisimiltude remained notably erudite in its allegiance to established formal aesthetics. Consequently, caricature and stereotyping dominated much of the working-class representation consumed by working-class audiences of the Victorian era. Concerns of authenticity continued with the emergence of novels set in northern industrial areas by writers such as Thomas Hardy, whose own class ascension fueled his investment in fidelity and the advancement of realistic character depiction. Working-class 
characters, such as Jude Fawley and Tess Durbeyfield, demonstrate elevation beyond their social designation through an emphasis on self-directed, contingent morality standing in contrast to the conventional morality of the Victorian era. Yet, in spite of authors like Hardy, whose own background granted his work rhetorical ethos, the policing of social class remained strong, as noted by George Orwell who, in a I940 interview, commented that even the most authentic working-class writers still operate within the confines of bourgeois literary production when aesthetic concerns take precedence over social objectives. ${ }^{2}$ Despite attempts to move beyond the bourgeois prejudice and stereotyping of the social novel, there were few writers active at the time with proletariat origins who were writing for specifically working-class people.

Despite a lack of established working-class voices in mainstream publishing, working-class writing by and for working-class people thrived in the margins of the latter part of the nineteenth century. Poets like Joseph Skipsey, whose work documented the rise and impact of mining culture, went largely unnoticed despite receiving praise from luminaries like Dante Gabriel Rossetti. It was also during this time that parochial working-class writing emerged in the form of the dialect literature of the I 860 s and I 870 , centered upon northern industrial towns like Durham and often associated with the phenomenon of the music hall. An example of such figures includes Edwin Waugh, whose emphasis on Lancashire dialect in poems like "Come whoam to thi childer an' me" underscore the nature of working-class life in a manner that speaks directly to a Lancashire audience. As Dave Russel has noted, dialect literature was intensely regional not just in vernacular, but also in methods of production and dissemination: "In Yorkshire, the major vehicle was the prose-oriented yearly comic almanac [whereas] in Lancashire, the monthly journal was the preferred form" (2004, pp. I I 8-I I9). Russel adds that local newspapers allowed regional writers to target specific audiences, and almanacs popularized during the 1870 s led to the rise of parochial voices that lingered well into the I950s (2004, p. I I9). ${ }^{3}$ Such texts were instrumental in establishing a strong sense of place overlooked in the more popular narratives, and the embrace of local color can be read as an analog to the more widely known regionalism emerging 
in late nineteenth-century American literature. However, whereas American regionalists such as Mark Twain and Kate Chopin focused on establishing a sense of place alongside narrative and character, the dialect poets' emphasis was primarily on the place itself, signaling the intimate link between language and landscape. Standing in contrast to the work of established late Victorian writers or sensationalist literature aimed at mass consumption, dialect literature reflects a kind of literature produced by and for the regions it represents-one that signals the importance of place and community as components of class consciousness.

Furthermore, Elizabeth Carolyn Miller has noted how the late Victorian period saw a rise in radical publishing as a direct counter to mass publishing, starting in the I 880 os with socialist papers such as Commonweal and Justice serving as vehicles for serialized novels from writers like George Bernard Shaw and Edward Carpenter. ${ }^{4}$ Analogous to the emergence of Finnish working-class publishing as outlined by Elsi Hyttinen and Kati Launis in this collection, the imperative was largely the same: the sustenance of alternative media currents designed to counter mass-market and more established forms of literary production. ${ }^{5}$ The kind of novels associated with this movement, Miller points out, reflects the Chartist struggle of incorporating social messaging within popular narratives and motifs. In particular, Miller notes how novels, such as Clementina Black's An Agitator (I 894), “collapse[s] under the weight of the bourgeois marriage plot or the novel of individual development" (2010, p. 707). Other novels of the time, Miller suggests, show signs of exploited revolutionary narratives as a spectacle by which to sell papers (2010, p. 708)-a gesture that signals the potential commodification of class identity that will form a contentious thread throughout twentieth-century workingclass literature. Although the late nineteenth century can be seen as a convoluted time in terms of publishing working-class writing, the period points to the persistence of paradoxes associated with working-class literature: the disharmony of realistic representation in relation to the desire for the spectacular; the burgeoning potential to commodify and sensationalize class identity; and the irresolute parallel trajectory of aesthetic and political objectives. Whereas the early nineteenth century saw the emergence of class 
forms, class consciousness, and the evolution of the novel itself, the late-nineteenth century can be viewed as a time in which tropes synonymous with British working-class literature gain traction.

\section{Twentieth-Century Literature: Evolution and Refinement}

It was the twentieth century, however, that saw the consolidation of nineteenth-century motifs into what would become known as proletariat literature. Yet due to the impact of both wars and the collapse of imperialism that followed, working-class writing continued to evolve, coming to full fruition in the late I950s following a period in which engineered nationalism took center stage. This nationalism echoed a utopian idealism, in which conceptions of class difference established in the nineteenth century were softened in an attempt to bolster national spirits. This was accomplished, in part, through the increased commercialization of music hall writing that emerged at the end of the Victorian period. Although music hall writing veers away from more traditional literary forms, the genre serves as a key component in understanding the development of British working-class writing in that it builds on the dialect literature of the Victorian era by commercializing parochial voices and projecting them onto a national stage. The egalitarian and somewhat utopian nature of the music hall resulted in a space in which working-class values were momentarily integrated with the values of the ruling class, resulting in a temporary haven from class discrimination and difference. Music halls amplified the voice of working-class writers who would otherwise have been limited to smaller, regional audiences. And early music hall writers, such as Thomas Hudson (a grocer), John Labern (a newspaper shop owner), and Sam Collins (a chimney sweep), often doubled as performers themselves, penetrating class barriers and advancing working-class attributes for national discourse largely through a musical format that helped distract audiences from the class-specific concerns of the lyrical content. According to Richard Anthony Baker, Queen Victoria herself was reported to have shown appreciation for the melody of a military band's rendition of "Come Where the Booze is Cheaper," oblivious to the working-class sentiment of the lyrics (20I4, p. 76). 
However, the popularity and spread of music hall writing also positioned it as a vehicle for the broadcasting of war propaganda. ${ }^{6}$ In this regard, it is possible to see the way working-class characteristics can be capitalized on, not just for commercial gain but for pernicious nationalism through the cooptation of class identity. Music hall performances were used to glamorize military service-especially in the years leading up to World War I-as an attempt to form a patriotic consensus. The writing of music hall content became an increasingly lucrative venture as popularity continued to boom with writers offering to "add 'a war verse' to any given song for a small fee" (Mullen, 20I6, p. I 53). Despite the music hall's reliance on contemporary issues, dissenting lyrics were initially kept from entering into performances but became more prominent following the war, suggesting how a genre can be reclaimed in light of commodification. The decline of the music hall during the interwar years is generally linked to the rise of cinema and the emergence of radio, but it was not until the I950s that John Osborne offered last rites to music hall culture in his I957 play The Entertainer. What this unique genre underscores is the way that regional working-class aesthetics can be seized upon and mobilized by forces external to the classes that they represent. This has significant bearing on representations of working-class people to this day and reveals the risk of systematizing class representation in a manner that can exploited for gain.

Despite the cooptation of working-class identities through music hall writing, literary representation of working-class people continued to develop in novels in a way that sustained tension between literary aesthetics and political objectives. Following writers like Thomas Hardy, whose realistic character depiction stemmed from his own lived experience, new connections between the aesthetic and the political were attempted by writers such as D.H. Lawrence, whose 1928 novel Lady Chatterly's Lover brought about tangible social change. Lady Chatterly's Lover paved the way for the inclusion of frank, taboo subject matter that would form a central motif of postwar literature. Lawrence's representations of working-class people were grounded in his own experience growing up in a working-class community in Nottingham and laboring in a factory as a clerk. However, then-contemporary 
critics like Christopher Caudwell aligned Lawrence with the artistic elite, due to the high-minded nature of his writing. This alignment rendered his representation of working-class people as suspect. Lawrence's use of taboo topics-especially surrounding the inter-class relations of Lady Chatterly's Lover-suggests a predilection to Victorian sensationalism but also reveals the complex role of gritty topics in fictional and aesthetic representations of the working-class.

Several important novels emerged during this time, however, that veered more toward the political than the aesthetic. Populist texts, such as Robert Tressell's The Ragged-Trousered Philanthropists (I9I4), found a more general readership due to a grounded use of language, yet their fidelity to the social elevation of working-class people was still questioned. Despite a slew of geographical inaccuracies and the elision of key historical events, Tressell's novel represented the broad cultural moment; and in contrast to writers like Lawrence, it reflected working-class solidarity through its depiction of shared struggle over modernist interiority and individualism. The enduring popularity of Tressell's text can be aligned to the common reader's ability to identify with the narrative in a manner that sets the aesthetic aspirations of Lawrence into stark relief. Other writers of the time, such as Harold Heslop and Henry Green, produced works that vacillated between pointed social critique and modernist experimentation. Heslop's The Gate of a Strange Field (1928) recounts the events of the 1926 General Strike, placing the author at the vanguard of inter-war working-class writing. As Charles Ferrall and Dougal McNeill have noted, Heslop envisioned a working-class literary revolution, declaring in 1930 at the Second Conference of Proletarian and Revolutionary Writers that texts such as his own faced an uphill struggle from editors and publishing houses which sought to attenuate revolutionary messaging (2015, p. I48). Green's Living (I929) can be seen as a precursor to the factory novels of the late 1950 s, employing strong regional dialects to represent Birmingham factory workers to the degree that the syntax itself reflected modernist experimentation. In contrast to Tressell, though, Green's novels were not well received by the general public, selling comparatively few copies even after receiving 
inordinate praise from W.H. Auden and Anthony Burgess. Despite attempts by writers such as Heslop and others to authenticate a proletarian literature, the tension between competing aesthetic and political objectives kept the movement from gaining necessary traction. It was Walter Greenwood's I 933 novel, Love on the Dole, that brought such objectives together most saliently, seeing large commercial success through its combination of authenticity and objective realism. Furthermore, Greenwood himself declared working-class allegiance as the son of radical working-class parents. Yet, as with Lawrence at the time, critics still questioned Greenwood's dedication to a working-class audience, noting how the novel's descriptions of classed environments were written to be understood by readers who would not be familiar with such spaces (Hentea, 2014, p. 47).

While Stephen Constantine has argued that Greenwood's text was partly responsible for shifting attitudes toward working-class people and working-class conditions (1982, p. 232), the rise of the modern welfare state illuminated the plight of the working class in a manner never before seen in British history. Katrina Clark, in this volume, draws attention to the "proletarianization" of Soviet Communism following the launch of the First Five Year Plan in I928, noting how white-collar representatives were replaced by blue-collar workers. The impact on Russian literature was a dethroning of the professional author, charging working people to produce their own stories based on their own experiences in the factory. Although no such role reversals took place in British culture, a "proletarianization" effect can be discerned in the rise of the welfare state and the elevation of working-class problems to that of a national concern. The I942 Beveridge Report took stock of the country's national health in the midst of war, calling for nation-wide sacrifices to elevate social conditions of the working classes, as well as those most directly impacted by the Blitz. Hugely popular, the report led to dramatic renovations in terms of public health, housing, and education, raising awareness to the severity of class-specific problems. The result was that, during the austerity period following the Second World War, a shared sense of desperation emerged in which previously overlooked class concerns were foregrounded in people's minds. This period, it 
might be said, cleared the territory for the avalanche of workingclass writing that followed.

But whereas Magnus Nilsson has noted how the interwar years represented the golden age for Swedish working-class literature due to the emergence of a specifically proletarian bildungsroman (see Nilsson in this collection), British working-class fiction of the same period lacked such aesthetic unity, emphasizing again the divide between form and function. However, the postwar years saw a culmination of working-class motifs united behind a concerted effort to move realism closer to the real. During the Second World War and the austerity period that followed, a discernible slump in realist depiction can be acknowledged and attributed to the modernist emphasis on experimentation. Additionally, the depictions of wretched lives were less salable as wretched realities washed over the country. Stuart Laing has noted how the decline in realist representation of working-class people can also be attributed to the closure of resources such as The Left Book Club (1948) and Penguin New Writing (I950)-venues that promoted topical, class-conscious texts (1986, p. 60). Consequently, the arrival of John Osborne's 1956 play Look Back in Anger caused pandemonium in the arts, closely followed by John Braine's novel Room at the Top (1957), Alan Sillitoe's Saturday Night and Sunday Morning (I958), and Shelagh Delaney's play A Taste of Honey (I958). These texts were grouped under the erroneous appellation of the "Angry Young Men," but the more appropriate descriptor is kitchen sink realisma simultaneous challenge to and revitalization of traditional realism through the elevation of working-class authenticity via documentarystyle representations of class.

The "Angry Young Man" label stems from a Royal Court Theatre press release characterizing the nature of John Osborne's most notorious protagonist. Indeed, Jimmy Porter-the play's central character-reflects an archetype that, alongside Sillitoe's Arthur Seaton, has situated him as a working-class cultural icon. Jim Dixon, the hapless protagonist of Kingsley Amis's Lucky Jim (I954) is often viewed as the original "Angry," but it was not until Osborne's play was released that critics looked back on Lucky Jim to view it within the context established by the kitchen sink 
movement. Amis's text certainly demonstrates aspects of the characteristic alienation expressed in the work of later "Angry" writers, but the similarity stops there. In fact, it can be argued that Keith Waterhouse's Billy Liar (I959) acts as a corrective by taking aspects of Jim Dixon and decanting him into a more suitable working-class context. The "Angry" texts mark a notable shift in working-class representation in that many of the characters demonstrate a distinct individual autonomy that suggests a disarticulation of the notion of class solidarity. Katrina Clark outlines a similar motif in her discussion of Soviet social realist novels of the I930s-a genre that, while distinct from the kitchen sink movement in several ways, draws a number of allegiances-arguing that, if a working-class hero exists, it is one characterized by self-governance: "a new working-class intelligenstia to supplant the rotten old one" (see Clark in this collection). Texts such as Saturday Night and Sunday Morning and A Taste of Honey provide clear-cut examples of working-class individuals renegotiating their class identity, in the same way that Colin Wilson's nonfiction work, The Outsider (I956) anticipates an emergent subculture and provides a theoretical framework for the "Angry" movement. For Sillitoe's Seaton, the dilemma is whether to rebel against social morays or to acquiesce and accept his designated status as a laborer like his father. Shelagh Delaney's Jo, however, is a character who (perhaps naively) refuses her social assignation and renegotiates her identity on her own terms. Whereas Eliot, Hardy, and others emphasized the importance of the individual within class confines, the "Angry" authors shift the focus toward individuals who potentially reject their assigned status. This shift signals a fracture in monolithic class identity and ushers in a new mode of class-consciousness that, while based in anxiety and despair, carries forth an optimistic charge.

Furthermore, the texts of this period take representation to new levels. On the one hand, the degree of gritty depictions associated with kitchen sink realism can be read as an aesthetic endeavor akin to Victorian spectacularization-a way to shock audiences of the time with candid representations of working-class lives rarely seen in the arts. On the other, a social function can be ascertained in that the writers of the time, comprehending the 
aesthetic limits of realism, pushed literature toward a more complete and accurate representation of British culture-one in which working-class people from northern industrial areas were shown to have a culture of their own. Eugenio Di Stefano's discussion of the testimonio in I960s South American literature draws striking parallels to the "Angry" authors in that both movements champion the role of subaltern voices within literary culture. According to Di Stefano, Testimonio is characterized by "simple, straightforward narratives" with rhetorical ethos operating "as an urgent call to mitigate a political injustice" (see Di Stefano in this collection). While the writers associated with kitchen sink realism certainly subscribe to motifs of local color and tend to rely upon archetypes, their focus is less of a direct response to injustice as it is a broad frustration to the welfare state's failure to eradicate the class concerns that the Beveridge Report sought to address. Much of the work produced during this time is deeply testimonial with writers such as Sillitoe and Delaney recreating the worlds in which they themselves were raised, lending the texts heightened legitimacy and speaking more directly to a working-class audience familiar with such environments. While nonfiction texts like George Orwell's The Road to Wigan Pier (1937) and Richard Hoggart's seminal The Uses of Literacy (I957) rely on the same kind of ethos central to the testimonio and the "Angry" text, both reveal a degree of sepia-tinged nostalgia more commonly associated with conventional representation. The texts of the kitchen sink realism movement largely sidestep nostalgia by presenting lived experience and the struggles unique to working-class people in a notably matter-of-fact way. Given this, the period in which Britain moved from postwar austerity to postwar affluence marks perhaps the most defined and forceful example of a unified proletarian literature to date.

Having said that, the kitchen sink era and the approaches its writers favored are not without their inconsistencies. As a relatively brief moment in cultural history, combined with the youthful antagonism of the movement, the period reads as electrified but with frayed wiring. It would be a stretch to suggest that kitchen sink realism offered a cohesive philosophy as (aside from Declarationa 1957 collection of essays penned by prominent figures of the 
movement) no singular manifesto or galvanized approach can be identified. Furthermore, despite the genuine class-based challenges faced by several of the movement's key figures, some were quick to distance themselves from their origins while keeping working-class culture central to their narratives. To suggest such a move as a betrayal to cultural origins would be unwise, but it does underscore once more the commercial viability of working-class representations and the ease by which such representations can be mobilized for aesthetic rather than political gain. Ironically, it was socially elevated writers such as Colin MacInnes who offered some of the most consistently vital and authentic depictions of working-class life during and after this time in The London Novels (I957-I960). MacInnes bridged on-the-ground journalism with narrative storytelling and surveyed the impact of urban gentrification on working-class people prior to the term entering into the lexicon. Similarly, E.R. Braithwaite's autobiographical To Sir, with Love (1959) offers a rare perspective on class and race by contrasting postwar London with colonial cultures. Braithwaite's novel stands out because of its depiction of a highly educated Guyanese immigrant helping underserved white working-class young men. This depiction underscores the complex intersections of race and class in Britain at the time. Despite such disparities between aesthetic and political objectives, the kitchen sink movement can be seen as a vector of past working-class literary tropes: the emphasis on gritty, visceral representation; the unflinching use of taboo subject material; the paradox of the individual within the collective; and personal testimony channeled as artistic and class-based insurrection.

To provide a comprehensive overview of the years that followed the kitchen sink movement is beyond the purview of this chapter, but the movement can be understood as a watershed-one whose impact can be felt throughout the five decades that followed across multiple media forms. The endurance of gritty television soap operas like Tony Warren's Coronation Street (I960-) and the emergence of the British New Wave film movement based upon adaptations of kitchen sink texts helped to cement the profound impact of the movement beyond its chronological parentheses. Comprehensive links can be drawn between the popular Wednesday Play series (I964-I970) and the emergence of Channel 4 television (I982) 
and its accompanying films-many of which were structured upon the work of the kitchen sink authors and relied upon the genre tropes codified during the period. Televised adaptations of novels like Nell Dunn's I963 Up the Junction for the BBC (I965) had direct impact on British life, such as foregrounding conversations around illicit abortions that led to the legalization of the procedure in 1967. The culmination of tropes galvanized during the I950s and I960s served literature well in terms of its efficacy to represent working-class culture as it was experienced. And whereas Magnus Nilsson in this collection registers a decline in Swedish working-class literature of the I980s and I990s, the Thatcher years in Britain saw an increase in working-class representation to oppose the political expediency of deindustrialization and neoliberalism by narrativizing its impact on communities in detail. Texts like Pat Barker's Union Street (1982) responded to the ensuing poverty of northern industrial regions stripped of their livelihood, whereas The Century's Daughter (I986) launched a thinly veiled attack on Tory policies. Work by James Kelman and Irvine Welsh followed a similar trajectory of raising working-class grit to the foreground as a response to the kind of political rhetoric of the time, in which the inhabitants of working-class communities decimated by deindustrialization were belittled for relying on social security nets established in the postwar years. The anger and social frustration expressed through the working-class literature of the I950s and I960s provided a working model for the I980s and I990s. It could not be more appropriate for today's world.

Furthermore, the rise in working-class representation of the I980s is fraught with racial tension as, following Conservative MP Enoch Powell's rabid "Rivers of Blood" speech in April of I968, working-class identities were mobilized as part of a nationalist effort to maintain a traditional English heritage through the reduction and reversal of immigration. Powell's contention was that prior waves of immigration posed an impending threat to British culture, responsible, he claimed, for an increase in violent crime in urban centers. In the words of Paul Gilroy, Powell's stance on immigration policy and his vocal opposition to the 1965 Race Relations Act-legislation that outlawed discrimination on the grounds of ethnicity and race-made claims that it "assists in 
the process of making Britain great again" in that it "restores an ethnic symmetry to a world distorted by imperial adventure and migration" (I992, p. 46). Powell's populist rhetoric aimed to link British working-class culture to nationalist concerns, suggesting that issues, such as unemployment, were the fault of non-white immigrants-the implications of which led to a series of hate crimes carried out amidst chants of the MP's surname. These claims found a surprising surge of support from white dock workers, miners, and laborers, who, according to Camilla Schofield, lacked the critical capacity to recognize their own manipulation by false rhetoric and narratives of disenfranchisement (20I3, p. 24I). As Gilroy adds, it was not until the I980s that many of these working-class supporters came to realize their role as political pawns and that, in terms of policy, they were viewed no differently from the racialized Other that Powell's speech scapegoated (I992, p. 34). Following the speech, Powell was promptly relieved from his position by then-party leader Edward Heath and his rhetoric widely condemned by his peers. Although Margaret Thatcher, the MP for the North London region of Finchley at the time, admitted that parts of Powell's speech were provocative, Powell's influence is perceptible through her subsequent politics of disenfranchisement, deindustrialization, and an emphasis on nationalism and retrograde cultural nostalgia masquerading as heritage. In response, the I980s saw a rise in multicultural and ethnic writing that complicated notions of British working-class cultural identities while commenting on Thatcher's neoliberal ideals of wealth acquisition, entrepreneurship, and forceful push toward individual responsibility under the guise of union busting and the dismantling of the welfare state. Screenplays such as Hanif Kureishi's My Beautiful Laundrette (I985) emphasized such incongruous ideals by placing cultural hybridity and community in conversation with seemingly irreconcilable notions of Randian libertarianism. Adapted as an award-winning and highly successful film by Stephen Frears, Kureishi's text reveals the inherent conflict of a proposed cultural identity that looks backwards while attempting to move aheadone that underscores Thatcher's vision for British culture.

Nevertheless, British working-class literature at the turn of the twenty-first century suggests adjustments to the formula established in the I950s, specifically through the amplification of past 
literary devices to a level that borders on hyperbole by moving representation from documentary-style realism to a state of exaggerated shock. One result from such a move is that the dividing line between drama and comedy becomes increasingly blurred in alignment with what has been termed as the New Sincerity and Post-Ironic movements. Additionally, the use of taboo subject material becomes so egregious that identification and schadenfreude are simultaneously engaged, depending on the reader's social position. In other words, twenty-first-century working-class writing retreats from realism, moving instead into the realm of caricature seen in nineteenth-century novels. This shift is motivated, it seems, by the commercial imperatives of overdetermined appeal. The fact that Paul Abbott's Channel 4 series Shameless (2004-20I3) won acclaim for both comedy and drama underscores the notion that the viewers' social positions dictate how the show is received: For working-class people, the world it depicts is grimly familiar; for others, the show is something else entirely. Twenty-first-century texts continue to favor gritty representations but now on a higher scale, resulting in working-class writing that pushes the envelope in terms of narrative shock value. Theater critic Aleks Sierz has discussed the rise of what he terms "In-Yer-Face Theatre," or the kind of writing that "grabs the audience by the scruff of the neck and shakes it until it gets the message" (200I, p. 4). Writers like Sarah Kane and Mark Ravenhill produced work that merged aspects of the edgier kitchen sink drama of the I960s such as Edward Bond's Saved (1965) with Artaud's Theatre of Cruelty through an amplification of sadistic sex, gratuitous violence, coarse dialog, and an undermining of narrative conventions-a post-ironic take on working-class literature of the past. While shock aesthetics are clearly at the heart of such representation-most pronounced in the commercial success of shows like Shameless or Skins, both of which saw phenomenal ratings and adaptations for international markets-the political aspirations of such extreme representation is considerably more opaque.

Similarly, Richard Milward's novel Apples (2007) tells the story of young people on a North Yorkshire housing estate in which class stereotypes run amok. Largely narrated in first-person by two teenagers, the depiction of classed space and class crisis is intensified to levels that border on parody. The fact that Milward's text 
emerged around the same period as Shameless and followed much of the same narrative logic, underscores the commercial appeal of gritty class-based representation that treads a fine line between depiction and cultural tourism. In the novel, Adam's domestic abuse at the hands of his father is presented in a manner that is both horrifying and darkly humorous, often within the same sentence. Eve's drug abuse and promiscuity dispenses vicarious thrills to the reader but in a manner that is just as troubling as Adam's harm. Poignantly, these depictions are emblematic of very real social problems that still plague parts of the country affected by the deindustrialization of the I980s. The degree by which comedy masks tragedy and vice versa is therefore rendered unclear. But the text characterizes a contemporary approach to representations of class that are aggressive and relentless in their grittiness, supplementing the lived-monotony of kitchen sink realism with a latent, disturbing brutality. On the one hand, it may appear that the barrage of aesthetic grit thrown into the realist machine in twenty-first-century British working-class writing appears as a purely commercial and soulless endeavor-one that either undermines realist representation or amplifies it to the level of simulacra, fully disengaged from the reality it portrays and devoid of any political objective. On the other hand, it reveals a critical component consistent across British working-class writing: the dynamic nature of representation that responds to both aesthetic and cultural shifts within the contextual moment. Given this, British working-class cultural production, by embracing tension between aesthetic and political objectives, maintains homeostatic flux that is critical to its longevity. To return to Peter Hitchcock's claim that working-class representation cannot be reducible to a series of material signifiers due to the fact that class is experienced as shifting social relations $(2000$, p. 23 ), the continual renovation of and resistance to a galvanized formal aesthetics reflects such a claim.

\section{Persistent Paradox and the Dynamic Tensions of Working-Class Writing}

Paradox and indeterminism, then, can be considered as characteristics threaded throughout the lineage of British working-class 
writing, emblematic of the kind of questions of authenticity that have plagued critical responses to working-class literature and, more significantly, underscoring the genre's capacity to adapt to cultural and aesthetic shifts in real time. Gauging the interplay between the form and the function of British working-class literature begins with an understanding of how such texts were received by the British public and the demands placed on cultural production. Chartist writing, for example, was aimed at a general audience in the hopes of enacting social change. Nonetheless, its success was hampered by the writers' inability to make largely didactic texts work within the framework of popular literary conventions. As Edmund Richardson has noted, Chartist writing was viewed as anachronistic in that reformist movements relied upon retrograde motifs in which "looking back to antiquity became a way to argue passionately for contemporary change" (2015, p. I I 8). Classical themes were presumed to add literary gravitas, but references to the ancient world were too outmoded to be taken seriously by readers of contemporary fiction. In this regard, the Chartists' failure to reconcile dual objectives implies a technical shortcomingpermissible given that the majority of the Chartist authors were not fiction writers at all. But in the context of working-class literature that followed, such early attempts at the reconciliation of form and function can perhaps be read as the catalyst of a productive tension inherent within working-class writing today.

Advances in publishing allowed for the expansion of print media to Victorian audiences, and many of the texts of the time were written with a wide readership in mind that bridged age, class, and gender. Although the novel as a format was still under construction during the Romantic period, innovations in distribution awarded Victorians wide access to texts. Novels, such as those penned by Dickens and Eliot, were popularized through serialization-a process that not only sustained readers' attentions over time but also reduced production cost. The result was increased access for middle- and working-class audiences. Consequently, the most commercial novels of the period often functioned as spectacles aimed at mass consumption, and in order to produce the spectacular effect, authentic depictions of class were sidelined in lieu of narrative structure and technical effects. 
As a result, representations of working-class people in popular Victorian novels were rarely more than two-dimensional foilsprops against which to establish more centralized characters. Positioning working-class characters in such a manner allowed the focus to remain on the spectacular form of the plot but lessened representational authenticity, limiting the text's function to produce tangible social effects.

The upshot of working-class audiences' appetite for sensational representation was addressed by Richard Hoggart who argued that consumption of commercial fiction resulted a "massifying" effect, or one that worked against the interests of working-class people by rendering them docile. Although attempts to counteract passive consumption of popular novels can be discerned throughout the working-class literature of the Victorian period, aesthetic form dominated over social function. And it was not until the kitchen sink movement that function was somewhat reconciled in texts where characters, scenarios, and problems directly reflected working-class lived experience. While it should be noted that several kitchen sink writers deployed social positioning to further their own aesthetic agenda, Kenneth Tynan's praise of John Osborne's infamous protagonist is telling:

The salient thing about Jimmy Porter was that we-the underthirty generation in Britain-recognised him on sight. We had met him; we had pub-crawled with him; we had shared bedsitting-rooms with him. For the first time the theatre was speaking to us in our own language, on our own terms" (Lichtenstein and Schregenberger, 2006, p. 284).

In their ability to connect with working-class people in a meaningful manner, postwar working-class texts restored equilibrium between aesthetic and political objectives through their capacity to exist alongside conventionally established literary forms while short-circuiting the massifying effect of popular media. This was accomplished by foregrounding working-class lives in a manner that reflected the new visibility of the underclass in the age of the modern welfare state. Whereas the readership of the past-which included working-class people-welcomed workingclass caricature as part and parcel of dominant literary trends, 
mid-twentieth-century literature signified an alignment of mimetic representation to then-current cultural concerns.

Yet the degree by which postwar working-class writers were motivated to diversify cultural representation in relation to their desire to undermine literary and theatrical conventions is rendered somewhat opaque, underscoring the productive tension of aesthetic and political objectives. Postwar writers were not simply writing for a marginalized audience as an altruistic venture; their aesthetic was equally grounded in artistic disobedience and a lucrative rebellion that put them on the literary map. Given the striking influence of mid-century cultural production on today's representations of the working-class, it is crucial to acknowledge the ease by which working-class grit can be packaged as a salable identity. This is especially significant given the way class-based narratives of the post-Thatcher years tend to amplify such representations as part of their enduring popularity. In this sense, the tension engaged between aesthetic and political objectives reads less as an effort to assuage discord and more as a strategic attempt at maximizing audience reception through broad appeal. Having said that, the texts of the I950s and I960s also laid the groundwork for important youth subcultural movements, so the upshot of enlarging target audiences through overdetermination is as much a gesture of ethics and social function as it is a gesture of commercial or aesthetic aggrandizement. A working-class text conveys significance in different ways depending on the social position of the reader. Consequently, the tension between aesthetic and political objectives can be read as less of an attempt at unification; instead, it functions more as a complication-a suspension that undermines, usurps, and revamps established literary norms and expectations throughout the evolution of working-class literature. Ultimately, what this suggests is that an intentional vacillation between form and function can be read as a persistent trope which responds to trends in both in society and the arts but also responds to trends in readership as well.

In addition to the effect of supply and demand, themes and motifs common to the genre also reflect historical contingency, underscoring British working-class literature's reluctance to be reduced to a set of formal components. As noted prior, working-class 
writing mirrors aesthetic techniques perceptible in other literary forms. However, the genre tends to politicize such techniques in order to increase their social function-a move recognizable in the use of taboo subject matter. When aesthetic motifs of formally established styles are adopted, they are often augmented for increased impact, either by revealing the limits of the original motif or reemphasizing its social dimensions. Such manipulation of motifs can be read as an opportunity to enrich prior literary techniques, while sustaining the tension between aesthetic and political objectives. Whereas Katrina Clark notes how Soviet writer Maxim Gorky sought to develop working-class writerly voices in opposition to established literary norms (see Clark in this collection), British working-class writing tends to work within established norms, updating rather than usurping them. For example, whereas realism of the past might skimp on working-class characterization for the sake of the plot, twentieth-century working-class texts grant extra dimension to working-class characters at the plot's expense, often by importing present-day social issues into their characters' psychological makeup. In this regard, working-class literature decouples from traditional realism through pointed, radical class advocacy. Its representations are more like insertions than repudiations, suggesting that the objective is not to redefine literary modes but to mobilize them more effectively. ${ }^{7}$

However, it is the postwar period that also reveals the paradox between the use of taboo topics to draw attention to social concerns and the potential to commodify such concerns for aesthetic elevation. Arguably, the writers associated with kitchen sink realism benefited from subject material that both challenged conventional morality and questioned the capacity of conventional morality to account for the lives of the entire populace. As virtually every film that emerged from the kitchen sink movement received a contemporary $\mathrm{X}$ rating-and many of the novels that they were based upon fell under similar scrutiny-the fine line between authentic representation of working-class issues and the exploitation of taboo as a marketable motif was rendered less clear. The I959 trial of D.H. Lawrence's Lady Chatterley's Lover played a critical role in the loosening of publishing restraints, granting writers greater leniency in relation to content. Furthermore, Richard Hoggart, 
testifying in the Lawrence trial, noted how the perceived shock of the novel was abrogated once the reader accepted the fact that the shock emanated not from the coarse language of the working-class characters, but from the mere existence of working-class characters within bourgeois environments. The shock effect was less the result of the text itself, and more the result of residual Victorian values that persisted well into the twentieth century. Given this, it is possible to see how the use of not just taboo topics but of vivid depictions of working-class life could act as marketable lure for upcoming writers looking to make a cultural impact. Discerning whether such motifs were deployed to raise social awareness of the dire conditions of working-class realities, to provide a more accurate overview of the British populace in the arts, or to simply shock audiences in a manner that echoed Victorian sensationalism, is rendered equivocal through the kind of paradoxical tensions permeating working-class literary aesthetics.

Yet the most recognizable trope associated with the formrealism-reveals a critique of literary techniques that pushes realism further than ever before. Benjamin Balthaser, in this collection, offers a strong argument against the conflation of realism with working-class literature by raising the question of form and function. Citing Georg Lukacs, Balthaser posits that class emancipation through writing should stem from literary secessiona clean break in which a uniquely subjective working-class voice can emerge distinct from established traditions (see Balthaser in this collection). While such concerns are apt-that a proletariat writerly voice might be compromised were it to emerge from within a bourgeois framework-the argument parallels the distinction between subculture and counterculture. Whereas counterculture operates in direct opposition to established norms, subculture emerges from within, carrying the potential to manipulate the dominant culture in the process. Much of the British working-class literature of the mid-twentieth century both anticipated and shaped radical subcultural developments that began in the I960s with the rise of youth subculture. Having said that, advances made in British working-class literature also serve to reveal the limits of realism in its capacity to push literary representation beyond the realm of aesthetic effect and into the realm of direct social usage. 
While realism's capacity to capture the real has long been contested, it might be said that gradations of verisimilitude exist, allowing for a rethinking of cultural fiction as indices of potential sociological data. Such gradations are based upon relative proximity to the real that raises questions as to whether ethnographic narratives like Hoggart's The Uses of Literacy are any closer to the real than works of fiction produced by authors with first-hand lived experience. ${ }^{8}$ In his brief study of verisimilitude in crime fiction, Tsvetan Todorov argues that written language can never attain the real as it will always be subjected to a subordinate referent, be it the "truth" of genre confines, public consensus of opinion, or verisimilitude's own rhetorical aim to sustain a mask of truth. In other words, language can depict authentically (realist fiction, for example), and can recount factual data (the lived struggles of working-class people, for example), but it is always subservient to the internal, autonomous laws of the medium. However, as Todorov reminds us, his own treatise of verisimilitude is not immune to this kind of interpellation. It holds allegiance first and foremost to the established confines of academic discourse, yet his "sentences participate in a different, a higher verisimilitude, and in that they resemble the truth" (I977, p. 88)..$^{9}$ In this regard, Balthaser's call for literary secession could result in a literature that is still subjected to rules of language and usage, never fully escaping the ideological influence of dominant culture or established literary conventions. Similarly, Peter Hitchcock considers the tension between political and cultural representation to be "a theoretical knot for literary criticism," warning steadfastly against the conflation of representation and culture (2000, p. 22). While workingclass literature does not untangle this theoretical knot per se, its awareness of realism's limits-and its desire to push against those limits as a bourgeois construction to be challenged-does suggest that concerns of realism's efficacy are still up for discussion and that the genre has the capacity to advance realist motifs further.

In agreement with Hoggart's concern over romanticized depictions of class (as well as the commercial viability of exploiting class identity), Tony Davies has noted how realist depictions in preand inter-war fiction have "often taken the form of a sentimental 
populism which seeks to conscript a radically simplified and unhistorical conception of the working class" (I984, p. I 26). Davies adds that, like realism, representations of working-class people are still demonstrations of "an aesthetic ideology with a specific history and discourse" (p. I 26). Obviously, this claim mirrors the ideological snare of verisimilitude sketched by Todorov, but Davies suggests that postwar representations of the working-class discard the sentimentality of the past to develop more visceral, graphic approaches while embracing the kind of "them and us" vexations of distrust outlined in Hoggart as recurring themes (I984, p. I26). For Davies, the prominence of characteristically gritty subject matter reflects "a more authentic tradition of proletarian realism: a profound suspicion of bourgeois ideologies and processes, particularly those that aspire to 'represent' the working class and its interests" (1984, p. I27). Davies clarifies that he is not seeking to conflate fact, fiction, and stereotypes, but rather to illuminate points of intersection that grant cultural fiction extra-literary worth, noting provocatively that

There is nothing at all to be gained from observing the academic protocol that questions of literary genre and tradition are one thing, those of political history and understanding another, and that they should have as little to do with one another as possible. The problem is rather to grasp both the difference and the inseparable through shifting kinds of relatedness between the terms; not in order to construct another 'theory of realism', but in an attempt to understand how and why a set of meanings mobilized by key words has become, historically, the locus of important and still unfinished transactions in the fields of culture and politics: in political culture, in cultural politics (I984, p. I27).

For Davies, characterizations of the working-class in postwar British fiction reflect less of a romanticized archetype in that fiction and lived experience become increasingly intertwined through the merging of social realism (a formal style) with socialist realism. This ideology coincides with the socialist imperatives underway in the development of the welfare state (1984, p. I3 I). Furthermore, the collaborative nature of the movement conveys an unusually high dedication to fidelity with documentary filmmakers, such as 
Tony Richardson, Karel Reisz, and Lindsay Anderson directing adaptations of the realist theatre of John Osborne and Shelagh Delaney while working with novelists like Alan Sillitoe and screenwriters such as Harold Pinter to produce films designed to be "more relevant than those made in the popular national cinema" (Dancyger, 20I4, p. I38). Although delineations do exist, there is an unmistakable impression of alliance during this period aimed at the intensification of realism and elevating verisimilitude to a level never before seen in British culture-one that is sustained through homeostatic tension. Therefore, if realism can be said to function on the sliding scale that Todorov conjectures, it would be at this particular moment that gritty representation in cultural fiction would parallel the representationally gritty ethnographic nonfiction approaches, such as that of Hoggart.

So, consistent from the Chartists to the present time is the question of intent: Is British working-class literature an aesthetic endeavor with self-aggrandizement in mind, or do working-class texts aim to engender social change through pointed social critique? What this survey hopes to have acknowledged is that, at any given moment, working-class literature reveals oppositional tracks that intertwine but rarely cohere. Therefore, as Sherry Linkon has noted of American working-class literature, such texts often require an effort to parse form and function, with Linkon adding how scholars of working-class texts should focus on "describing the qualities of working-class literary texts, rather than policing boundaries that define who has the authority to write them" (2010, n.p.).

However, as with concerns over the efficacy of literary realism, debates over the spiky topic of authority and legitimacy are difficult to jettison entirely. Citing architectural historian Luis E. Carranza, Eugenio Di Stefano reminds us in this volume that both formal experimentation and social function are inherently political, and Benjamin Balthaser outlines, in his essay, the negative impact of white authors representing ethnic minorities through the subsequent "racial dis-identification" observable in work by writers of color in the I930s. Whereas it is widely accepted in critical studies of literature that non-workingclass writers can represent working-class people and their 
attendant concerns with fidelity, such a claim does not hold so readily in terms of other social classifications, such as race or gender. Instead, concerns surrounding legitimacy reflect distinctions still made today between social classifications that clearly signify (such as race and gender) and classifications that do not (such as social stratification). Having said that, Linkon's point-that questions of authenticity should avoid rigid judgment-is well taken in terms of British working-class literature, especially during the Victorian era in which bourgeois writers' tendencies to stereotype working-class people are complicated by their genuine desire to enact progressive social change. In the twentieth century, this is complicated even further by "authentically" working-class writers who, in using their experience to further their own thematics, are granted social ascendency. ${ }^{10} \mathrm{My}$ point here is not to resuscitate settled debates surrounding legitimacy in the study of working-class literature, but to suggest that such concerns can be read as productive dynamics unique to the genre.

\section{Conclusion: The Direction of British Working-Class Literature}

In British society today, class is as politically charged a topic as ever. Although class boundaries are less stable than at the point of their formation, the capacity of literature to both critique and imagine future expressions of class consciousness is hard to ignore. Renewed interest in class-conscious independent presses and the arrival of collectives, such as the Northern Fiction Alliance, echo the heterodox publications of the Chartist movement, as well as the rise of the radical press at the turn of the twentieth century. This development suggests that continued efforts to present voices at the margins of established literary circuits are critical to class representation. While working-class imagery has become increasingly commodified as of late alongside the fetishization of Otherness, nontraditional voices and outlets endeavor to maintain homeostatic balance and prevent the total commodification of cultural histories and regional character. For example, in the wake of Brexit, novelist and essayist Nikesh Shukla suggested a collection from multiethnic working-class writers that was 
quickly crowd-funded for release through Dead Ink Press with Dead Ink director, Nathan Connolly, aiming for an anthology that "disproves myths and allows writers to challenge preconceptions about what it is like to be thought of as working class in twenty-first-century Britain" (Onwuemezi, 2016, n.p.). The mere existence of such projects and the production of minority ethnic working-class writing reaffirms the continual need to assess and monitor representations of class that follow aesthetic trajectories aimed at cashing in, suggesting how working-class representation should always exist within a state of dynamic tension.

What this chapter hopes to have accomplished is to reveal the way that British working-class literature presents a challenge to the literary techniques upon which it relies, mobilizing indeterminacy in a manner that renders such literature as historically contingent and dialogic. By adding grit to the realist mode, workingclass literature proves to be less of a problem of definition and more of a problem of categorization in that working-class texts refuse what are ultimately bourgeois artistic categories. The continual tension enacted between style, authenticity, and political objective is not a bug but a feature of working-class literature, addressing the difficulty of aligning ideological messaging with the kind of interpretative and symbolic frameworks associated with the literary arts. This tension, I suggest, mandates that working-class fiction continues to adapt to contemporary social concerns through the use of adapted literary techniques, refusing a fixed formal aesthetic and, therefore, curtailing the potential for commodification. The result is a state of aesthetic flux in which style, authenticity, and political objectives are rendered fluid without one focus necessarily privileging the other. In other words, a bourgeois writer can represent the conditions of workingclass experience with fidelity just as an authentically working-class writer can exploit his or her own class experience for a bourgeois cause. Therefore, the work of identifying what it is that makes a text proletarian is ultimately the work of the reader. Despite the emergence of tropes and technical choices clearly perceptible within a genealogy of British working-class writing, attempts to place a formal ceiling on such works is to restrict the kind of tensions that the genre requires to succeed. 


\section{Notes}

I. For anthologies, Ian Haywood's three collections are the most comprehensive (I995's The Literature of Struggle: An Anthology of Chartist Fiction and two volumes of Chartist Fiction from 1999 and $200 \mathrm{I}$ respectively). For additional critical writing on the topic, the Summer 200I edition of Victorian Poetry was devoted to working-class poetics with five contributions specifically looking at Chartist writing.

2. George Orwell, in a I940 interview with Desmond Hawkins, registered a discrepancy in class-conscious writing movements, stating that "I don't think the people who throw this expression about mean literature written by proletarians. W. H. Davies was a proletarian, but he would not be called a proletarian writer. Paul Potts would be called a proletarian writer, but he is not a proletarian. The reason why I am doubtful of the whole conception is that I don't believe the proletariat can create an independent literature while they are not the dominant class. I believe that their literature is and must be bourgeois literature with a slightly different slant" (I968, p. 38).

3. As Russel points out, echoes of dialectical literature in the form of almanacs can be identified in the rise of comics such as $\mathrm{Viz}$, in which both class and dialect are mercilessly skewered in questionable ways.

4. Miller also registers persistent canonical bias against working-class literature, noting how influential socialist papers like the Clarion have seen little in the way of academic scrutiny because they were aimed at and read by predominantly working-class audiences from the north (2010, p. 705).

5. It is worth noting here that the rise of radical publishing epitomizes a motif identifiable throughout working-class writing (as well as other forms of media production): an oppositional, subcultural gesture that serves to challenge dominant media forms, resulting in a continuous tension that prevents the commodification of the form.

6. Specifically, the Second Boer War (I899). While mentions of warincluding the First Boer War (I 880)—showed up in earlier Music Hall content, it was the second that certified its capacity as a tool of the state.

7. The insertion of class-specific social issues finds its origins in the Chartists and is developed in Late-Victorian realism, but an amplification 
can be identified within the I950s and I960s through the forceful embrace of taboo topics that serve to offset the class dominance of the arts. Topics such as abortion, domestic violence, alcoholism, and adultery were foregrounded during this time-a move that pushed the envelope of realism but also provided a spectacularized shock effect to audiences accustomed to morally homogenized media. It might be said that intensified realism, under the guise of kitchen sink realism, exposed the limits of traditional, bourgeois literary realism—an effect attained through the complicating of aesthetic and political goals.

8. For example, the difference between a documentary film that takes creative liberties in narration and a work of fiction that strives for absolute authenticity is, I would argue, up for debate.

9. Given that Todorov argues that the comprehension of verisimilitude as simply "consistent with reality" is a naive perspective that should be discarded $(1997,82)$, it follows that a gradational spectrum of verisimilitude can-and should-be considered.

Io. Writers such as Sillitoe, for example, distanced themselves from the culture central to their work, while authors like MacInnes-an upper-middle class writer-produced novels that depict class inequality with journalistic precision and was one of very few writers in working-class literary history whose work deals specifically with race.

\section{References}

Alcalá, R. del V. (2016). British Working-Class Fiction: Narratives of Refusal and the Struggle Against Work. London, Bloomsbury Academic.

Baker, R.A. (2014). British Music Hall: An Illustrated History. Barnsley, Pen \& Sword Books Ltd.

Braithwaite, E.R. (1959). To Sir, with Love. London, The Bodley Head.

Breton, R. (2009). Genre in the Chartist Periodical. In: A. Krishnamurthy, ed., The Working-Class Intellectual in Eighteenthand Nineteenth-Century Britain. Surrey, Ashgate, pp. I09-I 28.

Breton, R. (2016). The Oppositional Aesthetics of Chartist Fiction: Reading Against the Middle-Class Novel. Burlington, Ashgate. 
Casaliggi, C. and Fermanis, P. (2016). Romanticism: A Literary and Cultural History. Abingdon, Routledge.

Caudwell, C. (I97I). Studies and Further Studies in a Dying Culture. New York, Monthly Review Press.

Constantine, S. (1982). 'Love on the Dole' and its Reception in the I930s. Literature and History, 8 (2), pp. 232-247.

Dancyger, K. (2014). The Technique of Film and Video Editing: History, Theory, and Practice. CRC Press, Boca Raton.

Davies, T. (1984). Unfinished Business: Realism and Working-Class Writing. In: J. Hawthorne, ed., The British Working-Class Novel in the Twentieth Century. London, Edward Arnold, pp. I25-I36.

Eliot, G. (I998). Middlemarch. Ware, Wordsworth Editions.

Ferrall, C. and McNeill, D. (20I 5). Writing the 1926 General Strike. Cambridge, Cambridge University Press.

Foster, D.W. (1992). Contemporary Argentine Cinema. Columbia, University of Missouri Press.

Fox, P. (1994). Class Fictions: Shame and Resistance in the British Working-Class Novel, I890-I945. Durham, Duke University Press.

Gilroy, P. (1992). There Ain't No Black in the Union Jack: The Cultural Politics of Race and Nation. Abingdon, Routledge.

Hawthorne, J. (1984). The British Working-Class Novel in the Twentieth Century. London, Edward Arnold.

Haywood, I. (I997). Working Class Fiction: From Chartism to Trainspotting. Plymouth, Northcote House Publishers.

Hentea, M. (20I4). Henry Green at the Limits of Modernism. Sussex, Sussex Academic Press.

Hitchcock, P. (1989). Working Class Fiction in Theory and Practice: A Reading of Alan Sillitoe. Rochester, University of Rochester Press.

Hitchcock, P. (2000). They Must Be Represented? Problems in Theories of Working-Class Representation. PMLA, I I 5 (I), pp. 20-32.

Hoggart, R. (2009). The Uses of Literacy: Aspects of Working-Class Life. London, Penguin Classics. 
Janowitz, A. (I998). Lyric and Labour in the Romantic Tradition. Cambridge, Cambridge University Press.

Kirk, J. (2003). Twentieth-Century Writing and the British Working Class. Chicago, University of Chicago Press.

Klaus, H.G. (I985). The Literature of Labour: Two Hundred Years of Working-Class Writing. New York, Harvester Press.

Kovalev, Y. (1956). An Anthology of Chartist Literature. Moscow, Foreign Languages Publishing House.

Kureishi, H. (1996). My Beautiful Laundrette and Other Writing. London, Faber \& Faber.

Laing, S. (1986). Representations of Working Class Life, I957-1964. London, Palgrave Macmillan.

Lichtenstein, C. and Schregenberger, T. (2006). As Found: The Discovery of the Ordinary: British Architecture and Art of the I950s, New Brutalism, Independent Group, Free Cinema, Angry Young Men. Baden, Lars Müller Publishers.

Linkon, S.L. (20I0). Why Working-Class Literature Matters. [Blog] Working-Class Perspectives. Available at: https://workingclass studies.wordpress.com/2010/02/22/why-working-class-literaturematters [Accessed 23 March 20I 5 ].

Mahoney, C. (20I0). A Companion to Romantic Poetry. Oxford, Wiley-Blackwell.

Miller, E.C. (20I0). Literature and the Late-Victorian Radical Press. Literature Compass, 7 (8), pp. 702-7 I 2.

Milward, R. (2008). Apples: A Novel. New York, Canongate.

Mullen, J. (2016). The Show Must Go On! Popular Song in Britain During the First World War. Abingdon, Routledge.

Murphy, P.T. (I994). Toward a Working-class Canon: Literary Criticism in British Working-class Periodicals, I8I6-I 858 . Columbus, Ohio State University Press.

Newton, K.M. (20II). Modernizing George Eliot: The Writer as Artist, Intellectual, Proto-Modernist, Cultural Critic. London, Bloomsbury Academic. 
Onwuemezi, N. (2016). Northern Fiction Alliance Launches for Indies. [Blog] The Bookseller. Available at: http://www.thebook seller.com/news/indies-launch-northern-fiction-alliance-37 I 476 [Accessed I9 Oct. 2016].

Orwell, G. (1968). The Proletarian Writer: Discussion Between George Orwell and Desmond Hawkins. In: I. Angus and S. Orwell, eds., George Orwell: Volume 2, My Country Right or Left, I940I943. Boston, David R. Godine, pp. 38-44.

Richardson, E. (2015). Political Writing and Class. In: N. Vance and J. Wallace, eds., The Oxford History of Classical Reception in English Literature: Volume 4: I790-I880. Oxford, Oxford University Press, pp. I03-I29.

Rose, J. (2002). The Intellectual Life of the British Working Classes. New Haven, Yale University Press.

Russell, D. (2004). Looking North: Northern England and the National Imagination. Manchester, Manchester University Press.

Scheckner, P. ed. (1989). An Anthology of Chartist Poetry: Poetry of the British Working Class, I830s-I850s. New Jersey, Associated University Presses.

Schofield, C. (2013). Enoch Powell and the Making of Postcolonial Britain. Cambridge, Cambridge University Press.

Sierz, A. (200I). In-Yer-Face Theatre: British Drama Today. London, Faber \& Faber.

Southey, R. and Jones, J. ( I 836). Lives of Uneducated Poets, to Which are Added Attempts in Verse. London, H. G. Bohn.

Todorov, T. (1977). The Poetics of Prose. Translated from French by R. Howard. Ithaca, Cornell University Press.

Vicinus, M. (1974). The Industrial Muse: A Study of Nineteenth Century British Working-Class Literature. London, Croom Helm.

Watt, I. (I 957). The Rise of the Novel: Studies in Defoe, Richardson and Fielding. Berkeley, University of California Press.

Williams, R. (1958). Realism and the Contemporary Novel. Universities and Left Review, 4, pp. 22-25.

Wilson, N. (20I 5 ). Home in British Working-Class Fiction. Abingdon, Routledge. 
